\title{
Corylus türlerinin peyzaj tasarım çalışmalarında kullanılabilirliği
}

\author{
Ömer ATABEYOĞLU ${ }^{\circledR 1}$, Gülșah BİLGE ${ }^{\mathbb{D} 1}$ \\ ${ }^{1}$ Ordu Üniversitesi Ziraat Fakültesi Peyzaj Mimarlı̆̆ı Bölümü, Ordu \\ Alınıș tarihi: 28 Ekim 2019, Kabul tarihi: 30 Aralık 2019 \\ Sorumlu yazar: Ömer ATABEYOĞLU, e-posta: omeratabeyoglu@hotmail.com
}

\section{$\ddot{0} \mathbf{z}$}

Bitkisel tasarım, mekan tasarımına doğal materyallerin eklenmesini sağladığı için peyzaj tasarımının önemli aşamalarından birisidir. Bitkisel tasarım kadar, kullanılan bitki türleri de bu aşamada önem arz eder. Bitki türlerinin seçiminde, bitkilerin tasarıma katacağı estetik ve fonksiyonel katkılar önemli bir paya sahiptir. Bunun yanısıra, bitkilerin ekolojik istekleri ve adaptasyonları da bitki seçimi ve kullanım kararını etkiler. Böylece, bölgesine göre değișen son derece kısıtlı alternatifler bitkisel tasarımı şekillendirmektedir. $\mathrm{Bu}$ şartlar altında bölgenin doğal vejetasyonunda yer alan bitki türleri avantaj sağlar. Aynı zamanda doğal vejetasyonda yer alan türlerin aynı cinsten kardeş bireylerinin de adaptasyon ihtimallerinin yüksek oluşu alternatifleri artırmaktadır. $\mathrm{Bu}$ nedenle doğal vejetasyonda yer alan türlerin tercihi tasarımcılar için önemli bir artıdır. $\mathrm{Bu}$ durum bölgenin doğal bitki varlığının korunması ve kültürel kullanıma kazandırılması için de firsat oluşturur. Çalışmada, Karadeniz Bölgesi'nin hakim bitki varlıklarından ve temel ekonomik ürününden Corylus cinsi konu alınmıștır. Corylus cinsi farklı tür ve varyetelerinden oluşan bireylerinden özellikle fonskyionel ve estetik özellikleri ile ön plana çıkan bireylerinin peyzaj tasarımlarında kullanılması için farkındalığın artırılması çalışmanın temel amacıdır. Aynı zamanda bu bitkinin kentsel alan ve yaşam alanlarında kullanılması yenilebilir peyzaj olgusunu desteklemek açısından da değerlidir. Bu amaç doğrultusunda, literatür taraması ile Corylus tür ve varyetelerinden oluşan 5 türe ait 16 varyete incelenmiştir. Özellikle yaprak renkleri, formları ve ekolojik istekleri göz önüne alındığında kentsel ve kırsal peyzaj çalışmalarında findık bitikisinin alternatif bir süs bitkisi olarak kullanılableceği söylenebilir.
Anahtar kelimeler; Findık, Corylus, Karadeniz Bölgesi, Kentsel Alan, Peyzaj Tasarımı, Yenilebilir Peyzaj

\section{Use of Corylus spp in landscape design}

\section{Abstract}

Planting design which supports spatial design by adding natural materials is one of the significant phases of landscape design. The plant species used are as important as planting design itself at this phase. As aesthetic and functional features of species contributes to planting design, chosing the species are of the essence. In addition to that, adaptation ability and ecological needs of plants affect the decision while choosing and using those plants. Therefore, limited alternatives which differs from one region to another forms planting design. Under these circumstances, native plants could be seen as favorable choices. Also, this supports the possibility that species and varieties of these native plant genera could be highly adaptable. So, choosing the native plants benefits designers significantly. It also gives opportunity for conservation of native plants and their potential for cultural use. Corylus sp. which are dominant and one of the essential sources of income in the Blacksea region is chosen as the subject of this study. The main aim of the study is raising awareness of the use of Corylus taxa and its varieties in landscape design specifically the ones which have aesthetic and functional value. This is valuable from the perspective of supporting the idea of edible landscapes while using these species in urban areas and settlements. For that purpose, 16 plants including 5 species of Corylus and its varieties are chosen and examined with the help of literatüre 
review. It can be said that hazelnut plant can be used as an alternative ornamental plant in urban and rural landscape studies as the leaf colors, forms and ecological requirements.

Key words: Hazelnut, Corylus, Blacksea Region, Urban Area, Landscape Design, Edible landscape

\section{Giriş}

Süs bitkisi kavramı, ticari ve ekonomik kaygı gözetmeksizin fonksiyonel ve estetik özellikleri ile ön plana çlkan ve bu amaçla tercih edilen bitkileri tanımlar. Bitkilerde süs amaçlı aranan fonksiyonel ve estetik özellikler kullanılabilecek bitkileri oldukça sınırlandırır. Buna ekolojik istekler de dahil olunca tür çeşitliliği kısıtlanmaktadır.

Bir bitkiye süs bitkisi kazanımları sağlayan özellikler oldukça geniş bir çeşitliliğe sahiptir. Bitki çiçeği, yaprağı, dalları, dallanma şekli, gövdesi, formu, boyutları, tohumu ve meyvesi ile etkili olur. Bu etkiyi de bitkinin parçalarının şekli, rengi, dokusu ve yoğunluğu ile sağlar.

Corylus (Fındık) türleri önemli sayıda ve farklı özelliklerde çeşitliliğe sahiptir. Önemli bir ticari ürün olan Corylus cinsi taksonları, bu özelliği ile Karadeniz Bölgesi'nin önemli bir bölümünün bitki desenini oluşturur. Ülkemizde yaygın yetiștirilen fındık türü Corylus avellana L.'dır. Corylus colurna L. ise anavatanı ülkemiz olan ve "Türk fındığı" olarak bilinen, Kuzey Anadolu'da yaygın olarak yetişen önemli bir türdür (Ayan ve ark. 2016). Fındık ( $C$. avellana), Karadeniz Bölgesi'nin özellikle de orta ve doğu bölümlerinde yaygın olan bir bitkidir. Ancak, ticari olarak yetiştirilen bu türünün yaygınlığı ve çok gövdeli çalı biçimi nedeniyle görsel açıdan yeşil bir doku oluşturmaktan ileri gitmemektedir. Bölgenin iklim şartları ve coğrafik yapısına bu denli adapte olmuş ve bölge ile özdeşleșmiș, bölgenin simgesi haline dönüşmüş ve bölge sakinlerinin hayatında önemli yere sahip olmuş bir bitkinin farklı ve estetik özellikleriyle ön plana çıkan taksonlarının da kullanılması önemlidir. $\mathrm{Bu}$, doğal değerlerin korunması ve bölgenin doğasında yer alan türlerin değerlendirilmesi açısından da son derece önemlidir. Aynı zamanda bölge ve bitkinin marka değerinin artması, simgeleşmesi ve o bitkiye ait farklı türlerin kullanımı ile bir koleksiyonun oluşmasına katkı sağlayacaktır.

Fındık gibi meyveye sahip ve meyvesi nedeniyle ticari üretimi yapılan pek çok tür kentlerde ticari değerlerinin dışında estetik ve fonksiyonel özellikleri nedeniyle yaygın şekilde kullanılmaktadır. Yaygın hale dönüşmüş olmaları ve fonksiyonel ve estetik özelliklerinin göz önünde bulundurulması nedeniyle pek çok tür kentlerin plantasyonuna katkı sağlamaktadır.

Pek çok egzotik tür ile birlikte, bölgenin doğasında yer alan bitkilerin aynı veya benzer özelliklere sahip taksonların kullanılması plantasyonda bütünlügün sağlanması açısından da değerlidir. Bununla birlikte, fındık önemli bir yemiştir. $\mathrm{Bu}$ nedenle fındık bitkisinin kent içi düzenlemelerde kullanılması son yıllarda desteklenen ve çokça rağbet gören yenilebilir peyzaj olgusunun saha uygulaması olması açısından da önemlidir. Kentlinin kullandığı kent içi kamusal alanlardaki bitkilerin meyvelerinden yenilmesine imkan sağlayan yenilebilir peyzaj olgusu fındık için hem özel bir anlam hem de sembolik bir değer ortaya çıkartır. Nitekim Karadeniz Bölgesi'nde yer alan bazı kurumsal işletme bahçelerinde tek yada grup halinde veya kırmızı yapraklı fındık türlerine az da olsa yer verildiği görülmektedir.

$\mathrm{Bu}$ kapsamda çalışmanın amacı, dünya genelinde yetişen Corylus taksonlarından fonksiyonel ve estetik özellikleri ile öne çıkanların kentsel ve kırsal alanda kullanılabilirliğini tartışmak ve gündeme getirerek, ekolojik istekleri ve adaptasyon şartları da göz önünde bulundurularak yetişmeye uygun yerlerde kullanımının önünü açmaktır. Bu yolla hem kültürel plantasyonun korunması ve tasarlanmış alanlarda kullanımının değerlendirilmesi, hem de son yıllarda gündeme gelen yenilebilir peyzaj kavramını destekler şekilde plantasyona katkıda bulunmak hedeflenmiştir.

\section{Karadeniz Bölgesinde Fındık}

Corylus cinsi, Fagales takımı, Betulaceae (Huşgiller) ailesi, Coryloideae alt ailesinin bir üyesidir (Molnar, 2011). Dünya üzerinde kuzey yarıkürenin ılıman iklime sahip alanlarında doğal yetişme alanına sahiptir. Corylus türleri Kore, Japonya, Çin, Tibet, Hindistan, Kuzey İran, Türkiye, Kafkaslar, Avrupa ve Kuzey Amerika'da yayılış göstermektedir (Balık ve ark. 2016; İslam ve ark., 2018).

Ülkemizin Doğu Karadeniz Bölgesi, fındığın ana vatanı ve kültürünün de başlangıç yeridir. Aynı zamanda fındığın yetişmesi için dünyanın en uygun ekolojisine sahip yer de yine Türkiye'dir (Ustaoğlu ve Karaca, 2014; İslam 2018). Findık bitkisinin dünyadaki en yaygın olduğu ve dünyadaki en büyük üreticisi \%70 ile Türkiye'dir. Türkiye'den sonra ise \%12 ile İtalya, \%6 ile de Amerika'dır. Türkiye'de 705 bin hektar alanda 650 bin ton findık üretilmektedir. 
Fındığın çoğaltılması generatif, vejetatif, çelikle, aşı, daldırma, özelleşmiş gövde ve köklerle ve doku kültürü ile yapılmaktadır (İslam, 2018). Fındık bitkisi çoğunlukla alt bitki örtüsüdür, ancak direk güneş ışığı güçlenmeyi ve gelişmeyi sağlar. Fındık doğal bir şekilde çok çeşitli yetişme koşulları ve alanlarda bulunur. İyi drene olmuş ve nemli yerleri tercih eder ama kuru alanlarda da bulunabilir (Anon. 2019). Corylus için, $700 \mathrm{~mm}$ yıllık yağış ortalaması ve 13-16 ${ }^{\circ} \mathrm{C}$ arası sicaklık en uygun yetişme şartlarıdır (Köksal, 2002). Fındık çalı, ağaççık ve ağaç formlu, yaprağını döken bir bitkidir. Yaprakları çeşitlilik gösterir. Kenarları tırtıklı veya loblu ve saplıdır (Peiqiong ve Skvortsov 1999). Corylus avellana L. Ordu, Giresun, Samsun, Trabzon, Sakarya, Kocaeli ve Düzce illerinde, Corylus colurna ise Bolu ve Kastamonu illerinde yaygın olarak bulunmaktadır (İslam ve ark., 2018).

Bitkinin yetişme koşulları açısından bakıldı̆̆ında Doğu Karadeniz'de ortalama yıllık yağış miktarı Bayburt-Gümüşhane çevresi için 430-500 mm, Trabzon ve çevresi için 800-1400 mm, Rize ve çevresi için 1800-2000 mm'dir. Ylllık yağıș miktarı Orta ve Batı Karadeniz'de ise 700 -1000 mm'dir. Karadeniz bölgesinde kar yağışlı günlerin ortalaması 18 gündür. Yıllık ortalama sıcaklık $13-15^{\circ} \mathrm{C}$ 'dir. Ocak ayı ortalama sıcaklığ $6-7^{\circ} \mathrm{C}^{\prime}$ dir. Temmuz ayı ortalama sıcaklığ $21-23^{\circ} \mathrm{C}^{\prime}$ dir. Bölgenin güney kesimlerinde yağışlar azalır, sıcaklıklar düșer ve karasal iklim etkisi görülmeye başlar. Yaz yağışlarının yıllık toplam içindeki payı \%19.4 dır. Yıllık ortalama nispi nem \%71 dır (Sensoy ve ark. 2019).

Karadeniz dağlarının kuzeye bakan yamaçlarında nem isteği yüksek ağaç türlerinden oluşan nemli ormanlar yer alır. Karadeniz dağlarının eteklerinde 200-250 m'den itibaren kuzeye bakan yamaçlar boyunca nemli ormanlar ile sıcaklık isteği nispeten az, yağış isteği yüksek bitki formasyonları yer alır (Günal, 2013).

Çalışmada 5 türe ait, 16 takson ele alınmıștır (Erdoğan ve Mehlenbacher, 2002; Molnar, 2011; Ayan ve ark. 2016) (Çizelge 1).

\section{Süs Bitkisi Olarak Corylus}

Corylus, meyvesi çerez olarak tüketilen ve hammadde olarak değerlendirilen ticari bir ürün olmasının yanında dallanış biçimi, yaprak renkleri gibi özellikleri ile estetik ve fonksiyonel olan taksonlara da sahip bir bitkidir. Ülkemiz koşullarında ticari türleri yaygınlaşmıştır. Ancak, kentsel ve kırsal yeşil alanlarda estetik ve fonksiyonel özellikleri nedeniyle de etkili olarak kullanılabilir. Bitki, mevsimlere ve taksonlarına göre değişmekle birlikte meyve, çiçek, yaprak, gövde, dal, form ve rengi ile dikkat çekici özellikler göstermektedir (Çizelge 2).

Çizelge 1. Çalıșma kapsamında seçilen tür ve varyeteler

\begin{tabular}{|c|}
\hline Tür ve formu \\
\hline $\begin{array}{c}\text { Corylus maxima } \\
\text { Corylus maxima 'Purpurea' } \\
\text { Corylus maxima 'Atropurpurea' }\end{array}$ \\
\hline $\begin{array}{c}\text { Corylus colurna } \\
\text { Corylus colurna 'Obelisk' } \\
\text { Corylus colurna 'Terra Red' }\end{array}$ \\
\hline $\begin{array}{c}\text { Corylus heterophylla } \\
\text { Corylus fargesii }\end{array}$ \\
\hline $\begin{array}{c}\text { Corylus avellana } \\
\text { Corylus avellana 'Aurea' } \\
\text { Corylus avellana 'Atropurpurea' } \\
\text { Corylus avellana 'Red Majestic' } \\
\text { Corylus avellana 'Contorta' } \\
\text { Corylus avellana 'Contorta Red Majestic' } \\
\text { Corylus avellana 'Purple Umbrella' } \\
\text { Corylus avellana 'Red Dragon' } \\
\text { Corylus avellana 'Pendula' } \\
\text { Corylus avellana 'Fusco Rubra' }\end{array}$ \\
\hline
\end{tabular}

\section{Peyzaj tasarımı için önerilen Corylus türlerine ait} varyeteler

\section{Corylus maxima 'Purpurea'}

Yuvarlak formlu bir çalı olan bitki 4 - 5 m boy yapar. Hafif tekstürlü bir yapısı vardır. Gri kahverengi dallara sahiptir. Geniş oval şekilli, 8-14 cm büyüklüğünde yaprakları bulunur. Yapraklar baharda morumsu kırmızı, yazın ise morumsu yeșil ve koyu yeşil renk alır. Kahverengi-kırmızı renkli kedicikleri $10 \mathrm{~cm}$ uzunluğundadır. Meyveleri mor-kırmızı kabuklu, yenilebilir ve zehirsizdir. Tercihen kireçli, kumlu, kuru toprak ister. Soğuk iklim şartlarına toleranslı, dona ve rüzgara dayanıklıdır. Soliter veya çit için kullanımı uygundur. Bahçeler, parklar, çatı bahçeleri, mezarlıklar ve ağaç saksılarında kullanılabilir. Anavatanı İngiltere'dir (Şekil 1).

\section{Corylus maxima 'Atropurpurea'}

Boylu çalı ve ağaç formunda olup, $10 \mathrm{~m}$ boy yapar. Yaprakları yumarta şekilli, 7-12cm büyüklüğünde ve koyu kırmızı renklidir. Kedicikler 1,5-2,5 cm uzunluğunda ve sarı renklidir. Rüzgara dayanıklıdır. Güneşli ve yarı gölge yerleri sever. Anavatanı Kafkaslar ve Balkanlar'dır (URL, 2019i) (Şekil 2). 
Çizelge 2. Corylus bitkisinin karakteristik özellikleri

\begin{tabular}{|c|c|}
\hline $\begin{array}{l}\text { Bitkinin } \\
\text { organları } \\
\text { veya } \\
\text { özellikleri }\end{array}$ & Tasarıma katkısı \\
\hline Çiçek & $\begin{array}{l}\text { Erkek çiçekler püskül şeklinde, sarkık, sarı, bazen } \\
\text { kahverengi ve kırmızı renkli ve } 1.5-12 \mathrm{~cm} \\
\text { arasında değişen uzunluğa sahiptir. Dişi çiçekler } \\
\text { küçük kırmıı renklidir. Erkek çiçekler kedicik, } \\
\text { dişi çiçekler karanfil olarak isimlendirilir. Erkek } \\
\text { çiçekler dikkat çekicidir. Bitkiyi tanımlar ve } \\
\text { özelleștirir. }\end{array}$ \\
\hline Meyve & $\begin{array}{l}\text { Yuvarlak, uzun veya basık şekillidir. Meyveler, } \\
\text { kapsül şeklinde olup birkaç tanesi bir araya } \\
\text { toplanarak çotanağı oluşturur. Meyvenin } \\
\text { içerisinde bulunduğu çotanak yeşil, bazen de mor } \\
\text { veya kırmızı renklidir. Meyvesi ile çok dikkat } \\
\text { çekici değildir. Ancak meyvesi yenildiği için, } \\
\text { yenilebilir peyzaj çalışmalarında kullanılmaya } \\
\text { uygundur. }\end{array}$ \\
\hline Yaprak & $\begin{array}{l}\text { Yuvarlak, uzun şekilli, kıvrımlı ve } 7-14 \mathrm{~cm} \\
\text { aralığında değişen büyüklüktedir. Çoğunlukla } \\
\text { yeșil, koyu yeșil, sarı, morumsu kırmızı renklidir. } \\
\text { Bazı türleri sürekli morumsu kırmızı, kırmızı } \\
\text { renkli olup, bazı taksonlar mevsimle renk } \\
\text { değiștirir. Özellikle renkli yapraklı taksonları son } \\
\text { derece dikkat çekici olup, vurgulu ve etkili } \\
\text { görüntüler oluştururlar. Bitkinin estetik } \\
\text { bakımdan en özellikli kısmıdır. Tercihe göre farklı } \\
\text { renkli bitkilerin kullanılmasına imkan tanımas } \\
\text { tasarımlarda çeşitliliğe katkı sağlar. }\end{array}$ \\
\hline Gövde & $\begin{array}{l}\text { Çok gövdeli ve tek gövdeli türleri mevcuttur. } \\
\text { Gövde çoğunlukla gri kahverenkli olup, düzgün } \\
\text { yüzeylidir. Tasarımda kullanılacağ y yere karar } \\
\text { verme aşamasında gövde özelliği belirleyicidir. } \\
\text { Bazı türlerde gövde kabukları belirgin olmayan } \\
\text { parçalı olarak yarılmıștır. }\end{array}$ \\
\hline Form & $\begin{array}{l}\text { Türlere göre değişmek üzere çalı, ağaççık ve ağaç } \\
\text { şeklinde yuvarlak, dik ve dağınık formlara } \\
\text { sahiptir. }\end{array}$ \\
\hline Dallanma & $\begin{array}{l}\text { Dallar çoğunlukla gri kahverenklidir. Bazı } \\
\text { türlerinde dallar son derece kıvrımlı olup, estetik } \\
\text { görüntüler ortaya çıartır. }\end{array}$ \\
\hline Renklenme & $\begin{array}{l}\text { Bazı türlerinde yapraklar baharda morumsu } \\
\text { kırmızı, yazın ise morumsu yeșil ve koyu yeșil renk } \\
\text { alır. Yine bazı türlerinin kedicikleri ise kış sonu ve } \\
\text { bahar bașında pembemsi mor renk alır. }\end{array}$ \\
\hline
\end{tabular}

\section{Corylus colurna $\mathrm{L}$.}

Geniş oval, konik formlu, yarı geçirgen tekstürlü bir ağaç olup, $20 \mathrm{~m}$ boy yapar. Gri renkli kabuk ve dallara sahiptir. Yaprakları 8-12cm büyüklügünde, geniş ve koyu yeșil renklidir. Kedicikler $12 \mathrm{~cm}$ uzunluğunda ve sarımsı yeşil renklidir. Meyveleri yenilebilir. Toprak isteği bakımından seçici olmayıp, kumlu-tınlı toprak tercih eder. Soğuk iklime ve rüzgara dayanıklıdır. Cadde ve sokaklar, meydanlar, parklar ve mezarlıklarda kullanılabilir. Anavatanı Türkiye'dir (Şekil 3).
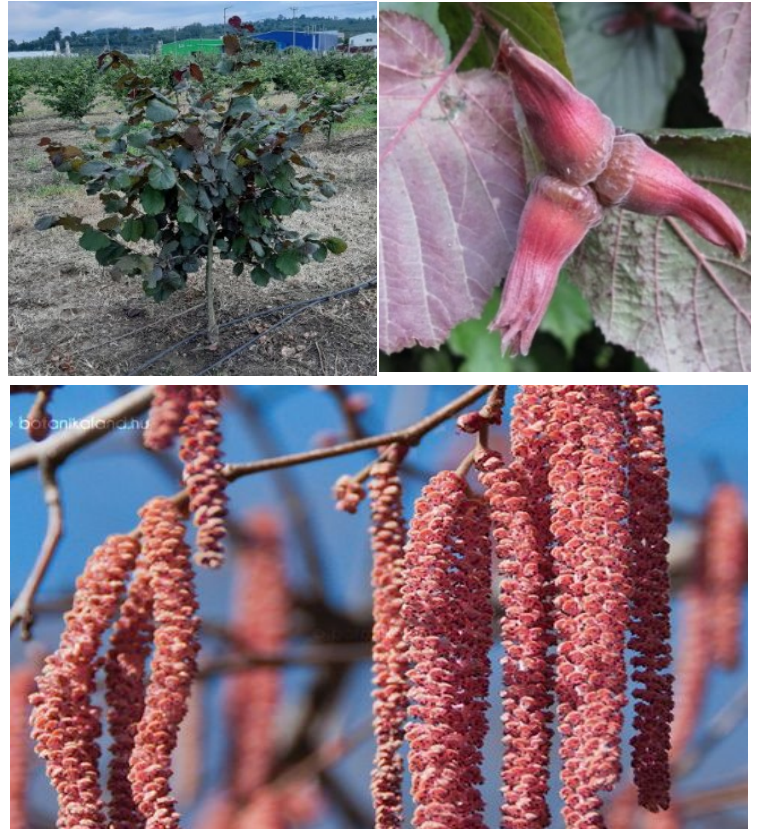

Şekil 1. Corylus maxima 'Purpurea' bitkisinin genel formu, yaprağı ve çiçeği $(1,2$. Orijinal foto: B. Öztürk, 3. URL 2019y).
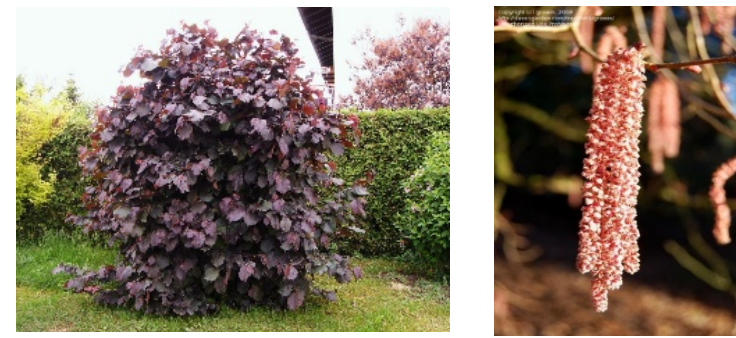

Şekil 2. Corylus maxima 'Atropurpurea' bitkisine ait form (URL, 2019a, y).

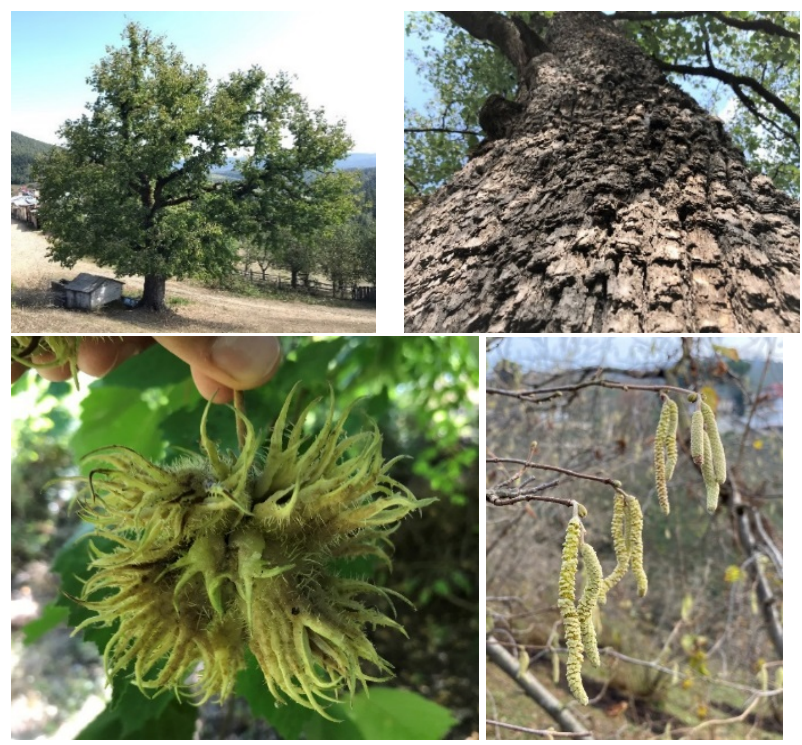

Şekil 3. Corylus colurna L. bitkisine ait görüntüler (Orijinal foto: A. İslam). 


\section{Corylus colurna 'Obelisk'}

Sütun formlu bir ağaç olup, 10-12 m boy yapar. Yarı geçirgen tekstürlüdür. Gri kahverenkli kabuk ve dallara sahiptir. Yaprakları 8-12 cm büyüklüğünde, gri yeşil renkli ve geniş oval formludur. Kedicikler 10 $\mathrm{cm}$ uzunluğunda yeşilimsi kahverengidir. Meyveleri çok az miktarda olup, yenilebilir niteliktedir. Tercihen kumlu ve kuru toprak ister. Soğuğa, rüzgara dayanıklıdır. Bulvarlar, parklar, caddeler, sokaklar ve mezarlıklarda kullanıma uygundur. Anavatanı Anadolu ve Avrupa'dır (Şekil 4).

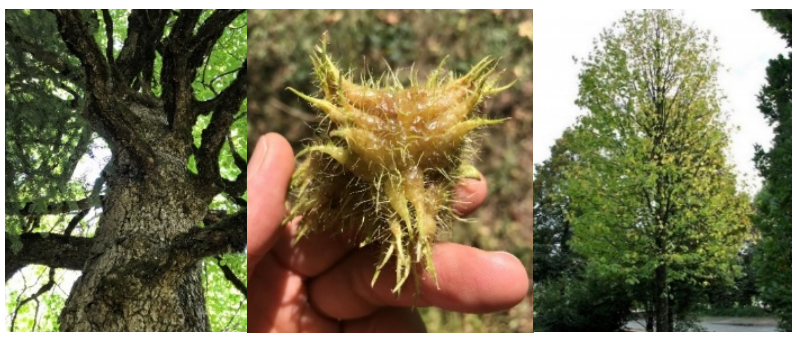

Şekil 4. Corylus colurna "Obelisk" bitkisine ait görüntüler (1, 2 Orijinal foto: A. İslam, 3 URL 2019y).

\section{Corylus colurna 'Terra Red'}

Konik ve yarı geçirgen tekstürlü taç yapısına sahip bir ağaç olup, $15 \mathrm{~m}$ boy yapar. Gri gövdeye sahiptir. Yaprakları 8-12 cm büyüklüğünde ve morumsu yeşil renktedir. Kedicikler, $12 \mathrm{~cm}$ uzunluğunda ve kahverengi kırmızı renklidir. Meyveleri yenilebilir özelliktedir. Tercihen kumlu toprak ister. Soğuk iklim şartlarına toleranslı, rüzgara dayanıklıdır. Büyük bahçeler, park ve bulvarlar, caddeler ve mezarlıklarda kullanılabilir. Anavatanı Avrupa'dır (URL, 2019h) (Șekil 5).
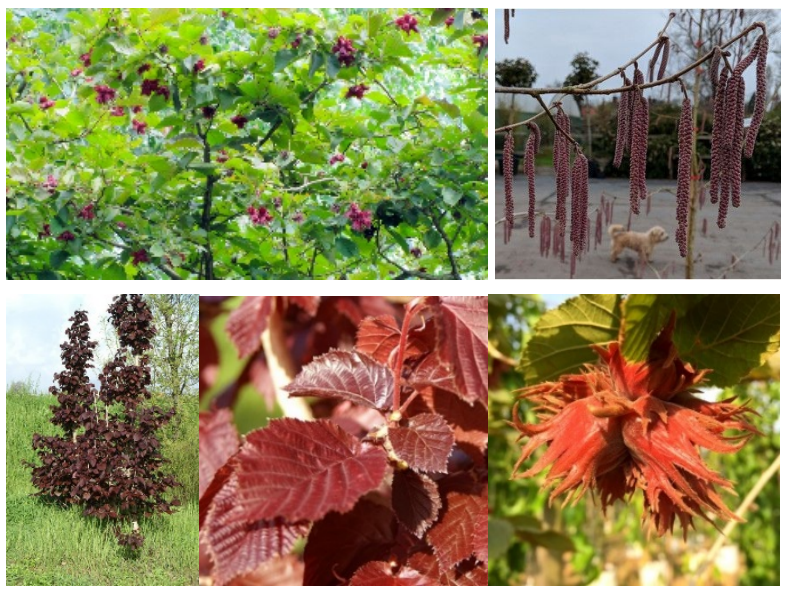

Şekil 5. Corylus colurna 'Terra Red' bitkisine ait görüntüler (URL, 2019y)

\section{Corylus heterophylla}

Çalı veya ağaççık formunda olup, $7 \mathrm{~m}$ boy yapar. Gövde kabuğu gri renklidir. Kedicikler yeșil renkli ve $4 \mathrm{~cm}$ uzunluğunda, diși kedicikler $3 \mathrm{~mm}$ ve parlak kırmızı renklidir. Yapraklar 4-13 cm uzunluğunda, 2,5-10 cm geniliğinde, yeşil renkli ve kenarları derin girintilidir. Yarı gölge sever. Her toprağa adapte olabilir, ama en iyi nemli topraklarda yetişir. Anavatanı Japonya, Çin ve Sibirya'dır (URL 2019s, d) (Şekil 6).

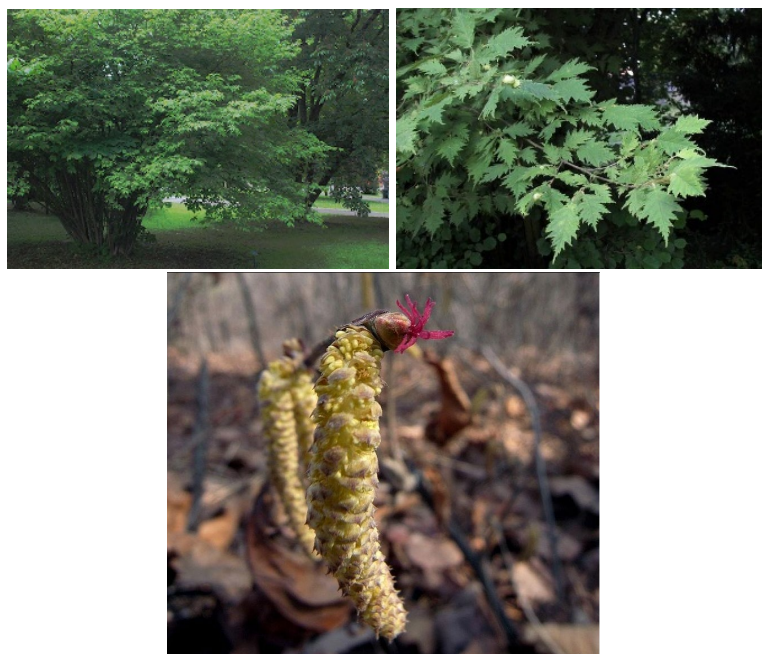

Şekil 6. Corylus heterophylla bitkisine ait görüntüler (URL 2019u)

\section{Corylus fargesii}

Büyük bir ağaç olup, $15 \mathrm{~m}$ boy yapar. Gövdesi yeşilimsi kahverengidir. Kedicikler, birkaçı bir arada $6 \mathrm{~cm}$ uzunluğunda ve kahverenklidir. Çiçekler sarımsı, kırmızı renkli, 2-4 tanesi bir arada, $5 \mathrm{~cm}$ uzunluğunda ve boru şekillidir. Çin'de 800-3000 m rakımda bulunur. Güneş ve yarı gölgeden hoşlanır. Güçlü rüzgarları tolare edebilir. Nemli toprakları tercih eder. Anavatanı Doğu Asya ve Çin'dir (URL 2019t, Aiello 2019, Schneid 2016) (Şekil 7).

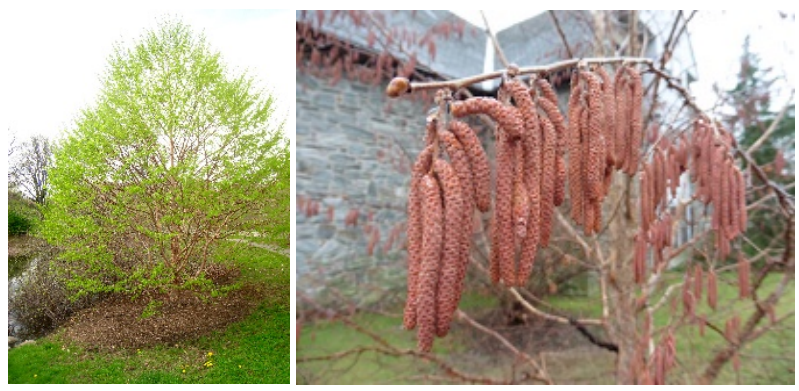

Șekil 7. Corylus fargesii bitkisine ait görüntüler (URL 2019 $\mathrm{g}, \mathrm{t}$ ) 


\section{Corylus avellana $\mathrm{L}$.}

Yüksek çalı veya ağaççık formunda olup, $5 \mathrm{~m}$ taç yapar. Yaprakları $10 \mathrm{~cm}$ büyüklüğünde ve ekolojiye ve gelişme durumuna bağlı olarak yeşilin farklı tonlarındadır. Erkek çiçekler 4-8 cm uzunluğundadır. İyi drene, tınlı topraklarda iyi yetişir. Anavatanı Türkiye'dir (İslam, 2018) (Şekil 8).
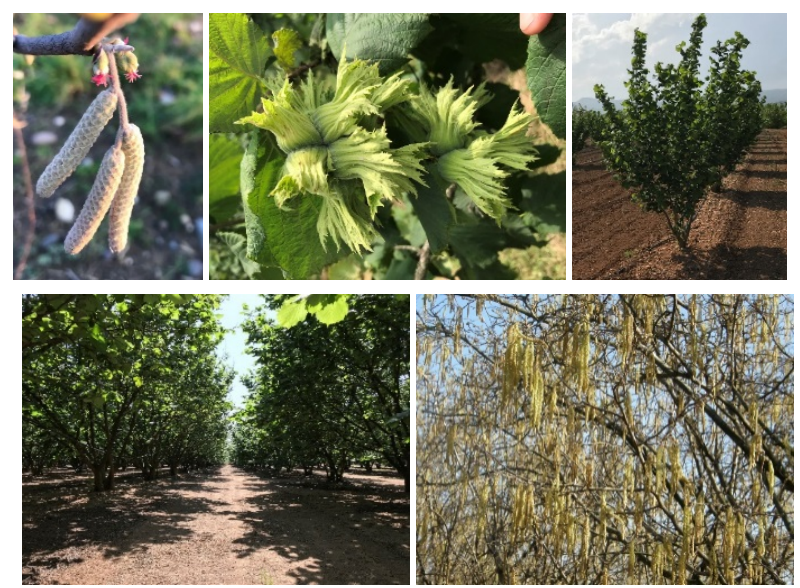

Şekil 8. Corylus avellana L. bitkisine ait görüntüler (Orijinal foto: A. İslam).

\section{Corylus avellana 'Aurea'}

İri çalı veya ağaççı formunda olup, $5 \mathrm{~m}$ boy, $5 \mathrm{~m}$ taç yapar. Yaprakları $10 \mathrm{~cm}$ büyüklüğünde ve sarımsı yeşil renklidir. Kedicikler 4-6 cm uzunluğundadır. Soğuğa dayanıklıdır ve güneşi sever. İyi drene olan topraklarda iyi yetişir. Anavatanı Türkiye'dir (URL, 2019j) (Şekil 9).

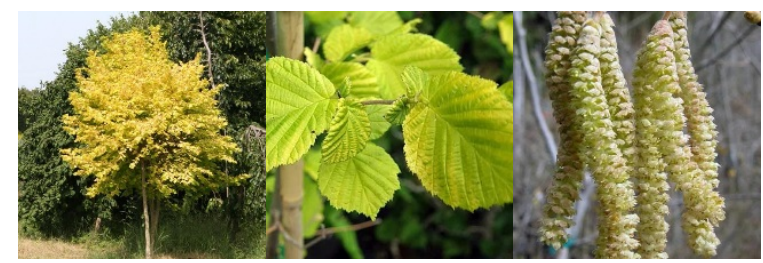

Şekil 9. Corylus avellana 'Aurea' bitkisine ait form, yaprak ve çiçek (URL, 2019j)

\section{Corylus avellana 'Atropurpurea'}

Büyük ve dekoratif formlu bir çalı olup, 4-5 m boy ve taç yapar. Yaprakları kırmızımsı renklidir. Soğuklara dayanıklıdır. Güneş veya yarı gölge sever. Zengin ve iyi drene olmuş toprak ister. Anavatanı Avrupa ve Türkiye'dir (URL, 2019m) (Şekil 10).

\section{Corylus avellana 'Red Majestic'}

Çalı formunda olup, 2,5 $\mathrm{m}$ boy ve taç yapar. Kıvrımlı dalları ile dikkat çeker. Kalp şeklinde, $10 \mathrm{~cm}$ uzunluğunda yapraklara sahiptir. Yapraklar, kedicikler ve meyveler kırmızı renklidir. Soğuk iklime dayanıklıdır. Bol güneş ister. İyi drene olan toprakları tercih eder. Anavatanı Türkiye ve Avrupa'dır (URL, 2019j) (Şekil 11).

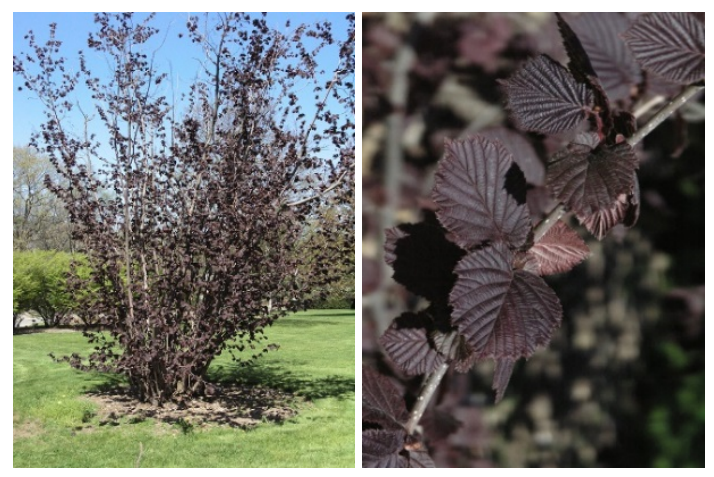

Şekil 10. Corylus avellana 'Atropurpurea' bitkisine ait form, yaprak ve (URL, 2019m)

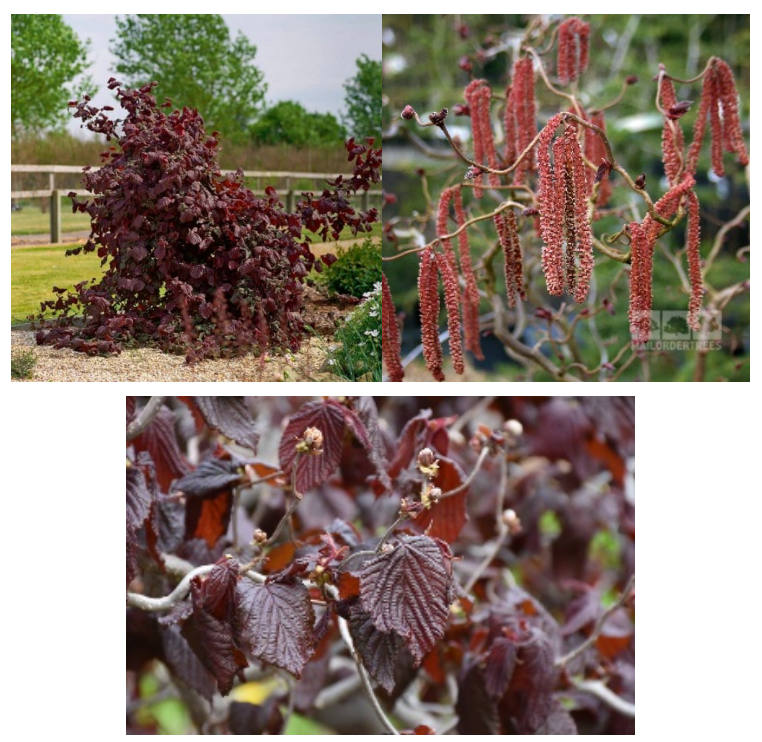

Şekil 11. Corylus avellana 'Red Majestic' bitkisine ait görüntüler (URL, 2019y).

\section{Corylus avellana 'Contorta'}

Çalı formlu bir bitki olup, 4-6 m boy yapar. Yuvarlak, yoğun ve dağınık bir taca sahiptir. Gri kahverenkli ve büklümlü dalları dikkat çekicidir. Yaprakları 4-10 cm büyüklüğünde, yuvarlak, çok kıvrımlı ve koyu yeşil renklidir. Kedicikler, 5-7 cm uzunluğunda kahverengimsi yeşil renklidir. Meyveleri yenilebilir. İyi drene olan ve kuru topraklarda iyi yetişir. Soğuk iklim şartları ve rüzgara dayanıklıdır. Parklar, bahçeler, mezarlıklar, çatı bahçeleri ve saksılar için uygundur. Soliter olarak kullanılabilir. Anavatanı İngiltere'dir (URL, 2019k) (Şekil 12). 

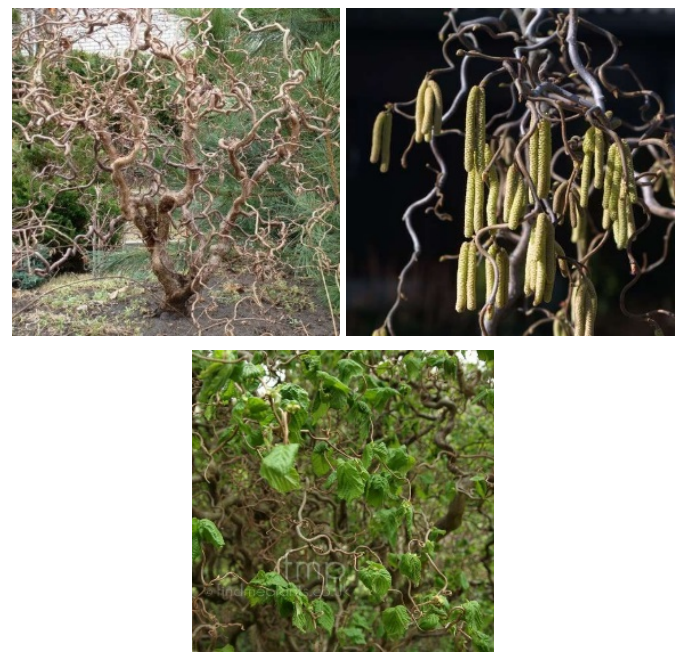

Şekil 12. Corylus avellana 'Contorta' bitkisine ait görüntüler (URL, 2019y).

\section{Corylus avellana Contorta Red Majestic}

Dağınık çalı formunda olup, 2,5 m boy ve taç yapar. Geniş kalp şekilli, $10 \mathrm{~cm}$ uzunluğunda ve kırmızı renkli yaprakları vardır. Dalları kıvrımlıdır. Kedicik ve meyveler kırmızı renklidir. Soğuklara dayanıklıdır. İyi drene olmuş toprakları ve güneşli ortamları sever. Anavatanı Türkiye'dir (URL, 2019k, l) (Şekil 13).
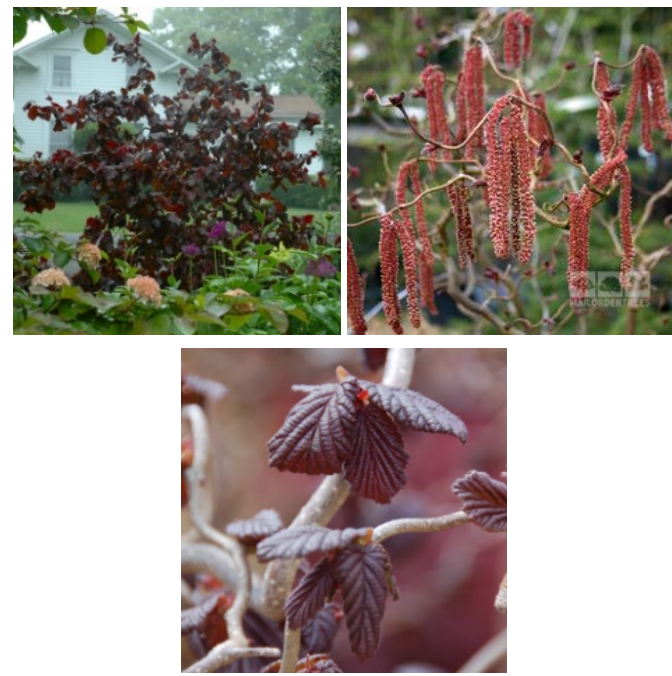

Șekil 13. Corylus avellana 'Contorta Red Majestic' bitkisine ait görüntüler (URL, 2019y).

\section{Corylus avellana 'Purple Umbrella'}

Sarkık formlu, küçük bir ağaç veya çalı olup, 2-2,5 m boy yapar. Yaprakları kalp șekilli ve gençlikte mor kırmızı, yaşlandıkça kırmızı yeşil renklidir. Toprak konusunda kanaatkardır. Soğuklara dayanıklıdır. Bol güneş sever. Soliter olarak ve ev bahçelerinde kullanıma uygundur (URL, 2019l) (Şekil 14).
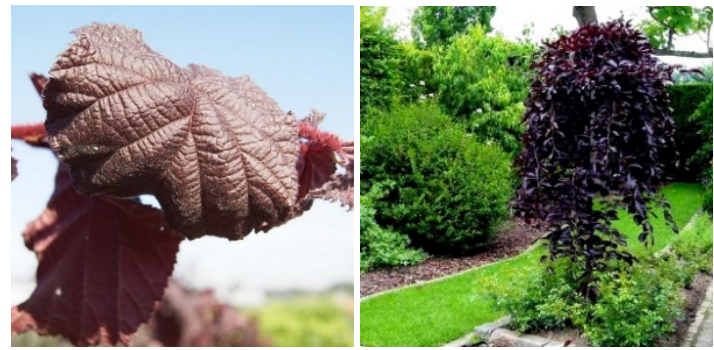

Șekil 14. Corylus avellana 'Purple Umbrella' bitkisine ait görüntüler (URL, 2019b, c)

\section{Corylus avellana 'Red Dragon'}

Yaygın ve dağınık bir forma sahip olup, $3 \mathrm{~m}$ taç, $4 \mathrm{~m}$ boy yapabilen çalı veya ağaççıktır. Yaprakları kırmızı renklidir. Dalları gri renkli ve bol kıvrımlıdır. Kedicikler, kırmızı renkli, birkaçı bir arada ve uzundur. Tam güneş veya hafif gölge sever (Şekil 15).
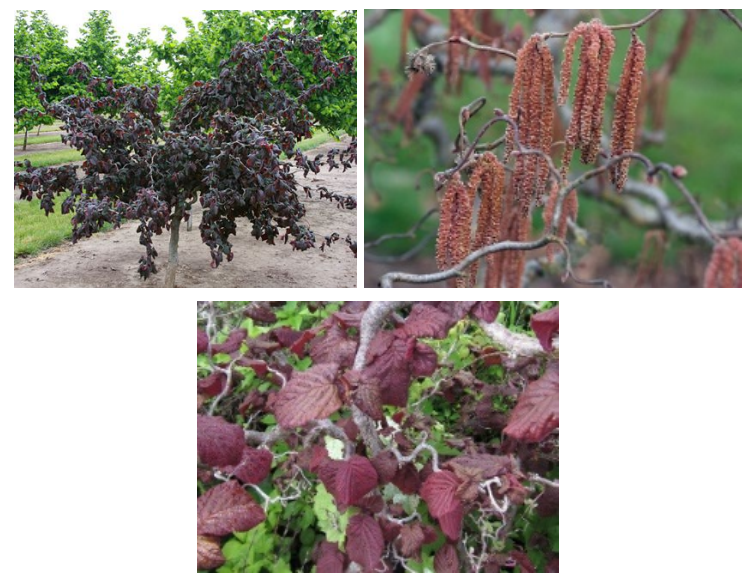

Şekil 15. Corylus avellana 'Red Dragon' bitkisine ait görüntüler (URL, 2019y).

\section{Corylus avellana 'Pendula'}

Yaprak döken bir bitki olup, 4-6 m boy, 3-5 m taç yapar. Soğuk iklim şartlarına uyumlu olup, güneş veya yarı gölge sever. Sarkık yapılı, küçük ağaççık formundadır. Kedicikler baharda yeşil renkli, yaprakları ise kalın ve koyu yeşil renklidir. Anavatanı Akdeniz Avrupası ve Doğu Asya'dır (URL, 2019n, ö) (Şekil 16).
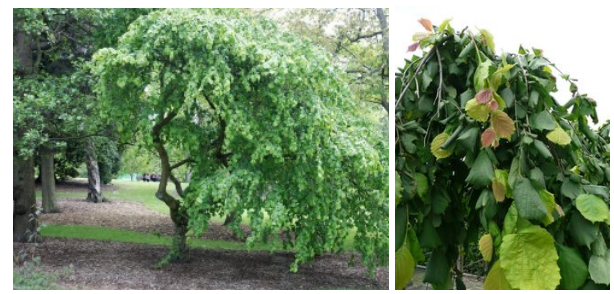

Șekil 16. Corylus avellana 'Pendula' bitkisine ait görüntüler (URL, 2019y). 


\section{Corylus avellana 'Fusco Rubra'}

Yuvarlak, şemsiye veya vazo formlu bir ağaççlk olup, 3-6 m boy yapar. Yaprakları morumsu yeşil renklidir. Gövdesi koyu kahverengi veya açık yeşil renklidir. Kış sonu ve bahar başında kedicikler pembemsi mor renk alır. Kısmi gölge veya güneş ile nemli ama iyi drene olan toprak tercih eder. Soğuklara dayanklıdır. Tuza dayanıksızdır. Sinonimi Corylus avellana 'Purpurea'dır (URL, 2019p, r) (Şekil 17).

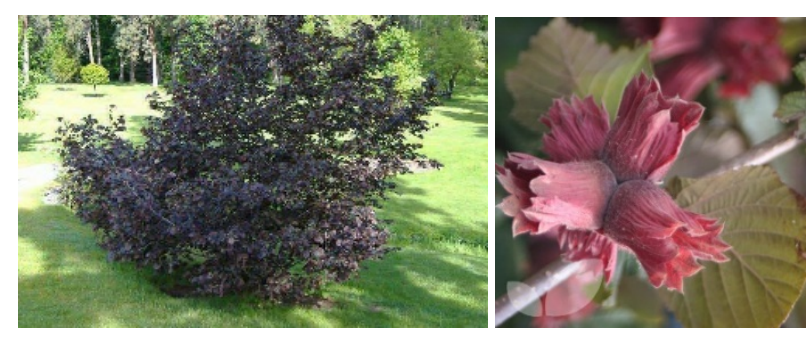

Şekil 17. Corylus avellana 'Fusco Rubra' bitkisine ait görüntüler (URL, 2019e, f)

\section{Corylus türlerinin süs bitkisi olarak kullanılmasına ilişkin genel değerlendirmeler}

Türkiye ve Karadeniz Bölgesi için önemli bir ticari ürün olan fındık, aynı zamanda bir süs bitkisi olarak da kullanım potansiyeline sahiptir. Özellikle çiçek, yaprak, dal, gövde özellikleri ve renklenmesiyle dikkat çeken türleri süs bitkisi olarak üretilme ve kullanılmaya değer özelliktedir. Bölgenin vejetasyon çeşitliliği yüksek olmasına rağmen, kültürel peyzaj alanlarında bölgenin doğal vejetasyonundan daha ziyade süs bitkisi olarak üretimi gerçekleştirilen ve yaygınlaştırılmış türler kullanılmaktadır.

Adaptasyonu sağlanmış ve geniş kullanım alanına sahip egzotik türlerin kullanımı tüm peyzaj alanları için önemli bir zenginliktir. Bu türler tasarımcılara, bitkisel düzenlemelerde estetik ve fonksiyonel nedenlerle kullanılabilecek pek çok alternatif sunar. Ancak, yerel türlerin ve doğal vejetasyonda yer alan bitkiler ile kardeş bireylerinin de bölgelerindeki bitkisel tasarımlara dahil edilmeleri alanda değerlendirilebilecek bitki alternatiflerini önemli miktarda artıracaktır. Aynı zamanda bölgenin iklim, toprak, su ve rakımdan kaynaklanan şartlarına adapte olmuş olan yerel bitkiler önemli avantajlar sunarlar. Yerel bitki türleri gibi kardeş bireyleri de çoğunlukla benzer yetişme şartları ararlar. Böylece kullanılabilecek bitki alternatifi daha da genişleyebilmektedir. Yerel bitkiler için bir adaptasyon endişesi duymak veya ne kadar iyi yetişebileceğini düşünmek gerekmediğinden hem karar verme aşamasını hem de bitkisel düzenlemenin çok daha hızlı kendini göstermesi için gerekli süreyi önemli ölçüde kısaltmaktadır. Aynı zamanda yerel türler halkın da aşina olduğu bitkiler olduğundan, yerli halkın gerçekleştirilen bitki düzenlemesini kabullenmesinde de etki sağlayacaktır. Zira yerel türler bölgenin kültürünü oluşturmaktadır.

Corylus taksonları özellikle bölge için önemli alternatifler sunmaktadır. Bölgeye uyum sağlamış olan olan özellikle Corylus avellana türü çok yaygın ve verimli bir şekilde üretilmekte ve kullanılmaktadır. Corylus'un diğer türleri de yakın ekolojik koşullara ihtiyaç duymaktadır. Bu da diğer pek çok Corylus türlerini bölgede kullanmaya, en azından deneme ve adaptasyon çalışmalarına elverişli kılmaktadır. Süs bitkisi açısından bu türlerden beklentinin meyve verimliliği olmaması bu bitkilerin alanda kullanılması için daha az gereksinim ve daha az kısıtlayıcı faktörün olması anlamina gelmaktadir.

Kaynaklar taranarak estetik ve fonksiyonel özellikleri ile seçilen toplamda 16 takson ana vatanları farklılık göstermesine rağmen, yetişme koşulları açısından birbirlerine yakın koşullara sahiptir. Bu koşullar ise büyük ölçüde Karadeniz Bölgesi koşullarına yakındır. Bu bitkilerin bölgeye kazandırılması ve kültürel peyzaj alanlarında kullanılabilir hale getirilmesi için önce bölge şartlarında denenmesi önemlidir. Böylece doğal adaptasyonu bulunanlar ile adaptasyon sağlamaya yatkın türler berlirlenmiş olacaktır.

Farklı anavatanlardan Corylus türlerinin hepsi meyveleri bakımından yenilebilir özelliğe sahiptir. $\mathrm{Bu}$ özellikleri ile kullanıldıkları yerlerde yenilebilir peyzaj olgusunu ve bölge kültürünü de destekleyeceklerdir. Ayrıca bölgenin ticari ürünü olan fındığın süs bitkisi ve yenilebilir peyzaj öğesi olarak kullanılması fındığın sembol değerini yükselterek bölgenin tanınırlığı ve imajı üzerine de olumlu etki sağlayacaktır. 
Çizelge 3. Corylus türlerinin süs bitkisi özellikleri bakımından değerlendirmesi

\begin{tabular}{|c|c|c|c|c|c|c|c|c|c|c|c|c|c|c|c|c|}
\hline & 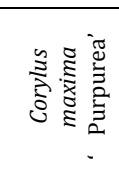 & 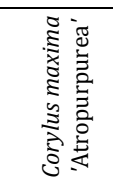 & 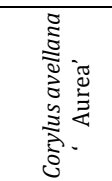 & 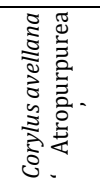 & 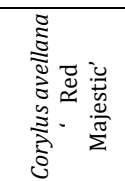 & 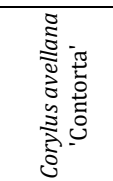 & 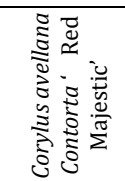 & 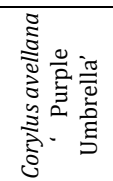 & 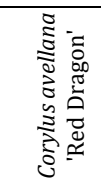 & 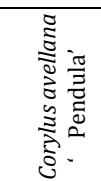 & 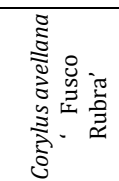 & 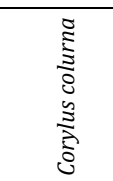 & 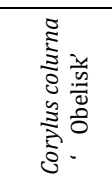 & 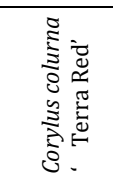 & 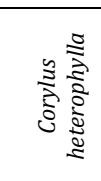 & 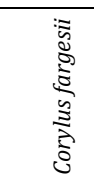 \\
\hline $\begin{array}{l}\text { Yaşam } \\
\text { formu }\end{array}$ & Çalı & Çalı, ağaç & $\begin{array}{c}\text { Çall, } \\
\text { ağaç̧,k }\end{array}$ & Çalı & Çalı & Çalı & Çalı & $\begin{array}{c}\text { Çall, } \\
\text { ağaç̧ık }\end{array}$ & $\begin{array}{c}\text { Çall, } \\
\text { ağaç̧ılk }\end{array}$ & Ağaççık & Ağaççık & Ağaç & Ağaç & Ağaç & $\begin{array}{c}\text { Calı } \\
\text { ağaç̧̧וk }\end{array}$ & Ağaç \\
\hline $\begin{array}{c}\text { Yaprak } \\
\text { rengi }\end{array}$ & $\begin{array}{c}\text { Mor } \\
\text { kirmıli, } \\
\text { mor yesil }\end{array}$ & $\begin{array}{c}\text { Koyu } \\
\text { kirmızı }\end{array}$ & Sarı yeșil & $\begin{array}{l}\text { Kirmizl, } \\
\text { bordo }\end{array}$ & $\begin{array}{c}\text { Kırmizl, } \\
\text { bordo }\end{array}$ & $\begin{array}{l}\text { Koyu } \\
\text { yeşil }\end{array}$ & Kırmızı & Kırmızı & Kırmızı & Yeşil & Mor yeşil & $\begin{array}{l}\text { Koyu } \\
\text { yeşil }\end{array}$ & Gri yeşil & Mor yeşil & Yeșil & Yeşil \\
\hline $\begin{array}{c}\text { Meyve } \\
\text { rengi }\end{array}$ & $\begin{array}{c}\text { Mor } \\
\text { kirmizi }\end{array}$ & & Yeşil & & Kırmızı & Yeşil & Kırmızı & & Kırmızı & Yeşil & Kırmızı & Yeşil & Yeşil & Kırmızı & Yeşil & Yeşil \\
\hline Kedicik & Kırmızı & Sar1 & Sar1 & & Kırmızı & $\begin{array}{c}\text { Kahve } \\
\text { yeșil }\end{array}$ & Kırmızı & & Kırmızı & Yeşil & $\begin{array}{c}\text { Pembe } \\
\text { mor }\end{array}$ & Sarı yeşil & $\begin{array}{c}\begin{array}{c}\text { Yeşil } \\
\text { kahve }\end{array} \\
\end{array}$ & Kahve & Yeşil & Kahve \\
\hline Form & Yuvarlak & Yuvarlak & Yuvarlak & Dağınık & $\begin{array}{l}\text { Dağınık, } \\
\text { sarkılk }\end{array}$ & $\begin{array}{l}\text { Yuvarlak } \\
\text { Dağınık }\end{array}$ & Dağııık & Sarkık & Dağııık & Sarkık & $\begin{array}{c}\text { Yuvarlak } \\
\text { Şemsiye, } \\
\text { vazo }\end{array}$ & $\begin{array}{c}\text { Geniş } \\
\text { oval, } \\
\text { konik }\end{array}$ & Sütun & Konik & Dağııık & Dağınık \\
\hline Tekstür & Yoğun & Yoğun & Yoğun & Hafif & Yoğun & Yoğun & Hafif & Hafif & Hafif & Hafif & Orta & Orta & Orta & Orta & Yoğun & Orta \\
\hline $\begin{array}{c}\text { Gövde, } \\
\text { dal }\end{array}$ & $\begin{array}{c}\text { Cok } \\
\text { gövde, } \\
\text { gri, } \\
\text { kahve } \\
\end{array}$ & $\begin{array}{c}\text { Cok } \\
\text { gövdeli }\end{array}$ & $\begin{array}{c}\text { Tek } \\
\text { gövdeli }\end{array}$ & $\begin{array}{c}\text { Cook } \\
\text { gövdeli }\end{array}$ & $\begin{array}{l}\text { Kivrıml } \\
\text { dallar }\end{array}$ & $\begin{array}{l}\text { Kivrimlı } \\
\text { dallar }\end{array}$ & Kıvrımlı & $\begin{array}{c}\text { Tek } \\
\text { gövdeli }\end{array}$ & $\begin{array}{c}\text { Çok } \\
\text { gövdeli } \\
\text { kıvrımlı }\end{array}$ & $\begin{array}{c}\text { Tek } \\
\text { gövdeli, } \\
\text { kıvrımlı }\end{array}$ & $\begin{array}{l}\text { Dağınık, } \\
\text { çok } \\
\text { gövde }\end{array}$ & $\begin{array}{c}\text { Gri } \\
\text { kabuk ve } \\
\text { dal }\end{array}$ & Gri kahve & $\begin{array}{c}\text { Gri } \\
\text { büklümlü }\end{array}$ & Tek, gri & Tek \\
\hline $\begin{array}{l}\text { Estetik } \\
\text { değeri }\end{array}$ & $\begin{array}{c}\text { Yaprak, } \\
\text { kedicik } \\
\text { rengi, } \\
\text { form }\end{array}$ & $\begin{array}{c}\text { Yaprak } \\
\text { rengi, } \\
\text { form }\end{array}$ & $\begin{array}{l}\text { Yaprak } \\
\text { rengi, } \\
\text { form }\end{array}$ & $\begin{array}{c}\text { Yaprak } \\
\text { rengi }\end{array}$ & $\begin{array}{c}\text { Yaprak, } \\
\text { meyve ve } \\
\text { kedicik } \\
\text { rengi, } \\
\text { form } \\
\end{array}$ & $\begin{array}{l}\text { Kivrımlı } \\
\text { dallar }\end{array}$ & $\begin{array}{c}\text { Yaprak, } \\
\text { meyve ve } \\
\text { kedicik } \\
\text { rengi, } \\
\text { form } \\
\end{array}$ & $\begin{array}{l}\text { Yaprak } \\
\text { rengi, } \\
\text { form }\end{array}$ & $\begin{array}{l}\text { Yaprak } \\
\text { rengi, } \\
\text { form }\end{array}$ & Form & $\begin{array}{c}\text { Yaprak, } \\
\text { meyve ve } \\
\text { kedicik } \\
\text { rengi, } \\
\text { form } \\
\end{array}$ & Form & Form & $\begin{array}{c}\text { Yaprak, } \\
\text { meyve ve } \\
\text { kedicik } \\
\text { rengi, } \\
\text { form, dal } \\
\end{array}$ & $\begin{array}{l}\text { Form, } \\
\text { doku }\end{array}$ & Form \\
\hline $\begin{array}{c}\text { Fonksiyo } \\
\mathrm{n} \text { değeri }\end{array}$ & $\begin{array}{l}\text { Gurup, } \\
\text { soliter, } \\
\text { perde, } \\
\text { snnr, } \\
\text { erozyon }\end{array}$ & $\begin{array}{l}\text { Gurup, } \\
\text { soliter, } \\
\text { perde, } \\
\text { sinır, } \\
\text { erozyon }\end{array}$ & $\begin{array}{l}\text { Gurup, } \\
\text { soliter, } \\
\text { gölge }\end{array}$ & $\begin{array}{l}\text { Gurup, } \\
\text { soliter, } \\
\text { erozyon }\end{array}$ & $\begin{array}{l}\text { Gurup, } \\
\text { soliter, } \\
\text { maske }\end{array}$ & $\begin{array}{l}\text { Gurup, } \\
\text { soliter, } \\
\text { maske }\end{array}$ & $\begin{array}{l}\text { Gurup, } \\
\text { soliter, } \\
\text { maske }\end{array}$ & $\begin{array}{l}\text { Gurup, } \\
\text { soliter, } \\
\text { maske }\end{array}$ & $\begin{array}{l}\text { Gurup, } \\
\text { soliter, } \\
\text { sinır, } \\
\text { erozyon }\end{array}$ & $\begin{array}{l}\text { Gurup, } \\
\text { soliter, } \\
\text { gölge }\end{array}$ & $\begin{array}{l}\text { Gurup, } \\
\text { soliter, } \\
\text { sunir, } \\
\text { erozyon }\end{array}$ & $\begin{array}{l}\text { Gurup, } \\
\text { soliter, } \\
\text { gölge }\end{array}$ & $\begin{array}{l}\text { Gurup, } \\
\text { soliter, } \\
\text { gölge }\end{array}$ & $\begin{array}{l}\text { Gurup, } \\
\text { soliter, } \\
\text { sınır }\end{array}$ & $\begin{array}{l}\text { Gurup, } \\
\text { soliter, } \\
\text { gölge, } \\
\text { perde }\end{array}$ & $\begin{array}{c}\text { Gurup, } \\
\text { soliter, } \\
\text { gölge }\end{array}$ \\
\hline
\end{tabular}

Çizelge 4. Bitkisel tasarımda Corylus' un kullanımı

\begin{tabular}{|c|c|c|c|c|c|c|c|c|c|c|c|c|c|c|c|c|}
\hline & き & 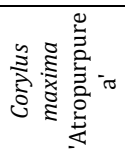 & 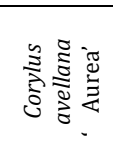 & 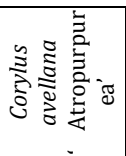 & 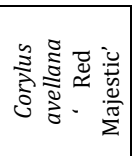 & 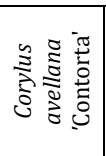 & 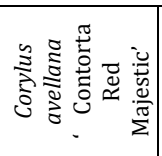 & 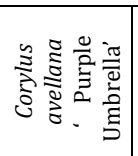 & 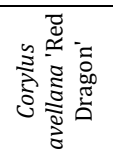 & 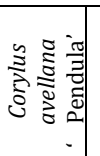 & 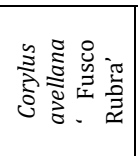 & ) & 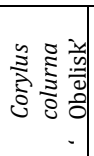 & 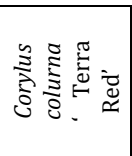 & 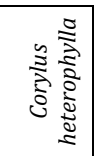 & 胥: \\
\hline $\begin{array}{l}\text { Dendrolojik } \\
\text { Özellikler }\end{array}$ & $\mathrm{b}, \mathrm{c}, \mathrm{d}, \mathrm{h}$ & $\mathrm{b}, \mathrm{c}, \mathrm{d}, \mathrm{h}$ & $\mathrm{b}, \mathrm{c}, \mathrm{d}, \mathrm{h}$ & $\mathrm{a}, \mathrm{d}, \mathrm{h}$ & $\mathrm{b}, \mathrm{c}, \mathrm{d}, \mathrm{h}$ & $a, b$ & $a, b, f$ & $\mathrm{a}, \mathrm{c}, \mathrm{d}, \mathrm{h}$ & $\mathrm{a}, \mathrm{d}, \mathrm{h}$ & $\mathrm{a}, \mathrm{c}, \mathrm{h}$ & $\mathrm{d}, \mathrm{h}$ & $\mathrm{a}, \mathrm{b}, \mathrm{c}$ & $a, b, c$ & $\mathrm{~d}, \mathrm{f}, \mathrm{h}$ & b, c & $a, b, c$ \\
\hline $\begin{array}{c}\text { Fonksiyonel } \\
\text { kullanım }\end{array}$ & $\mathrm{a}, \mathrm{b}, \mathrm{f}$ & $\mathrm{a}, \mathrm{b}, \mathrm{f}$ & $\mathrm{a}, \mathrm{b}, \mathrm{f}$ & $a, b, f$ & $a, b, f$ & $a, b, f$ & $a, b, f$ & $a, b, f$ & $\mathrm{a}, \mathrm{b}, \mathrm{f}$ & $\mathrm{a}, \mathrm{b}, \mathrm{f}$ & $\mathrm{a}, \mathrm{b}, \mathrm{f}$ & $\begin{array}{c}\mathrm{a}, \mathrm{c}, \mathrm{d}, \mathrm{e}, \\
\mathrm{f},\end{array}$ & $\mathrm{a}, \mathrm{c}, \mathrm{f}$ & $\mathrm{a}, \mathrm{b}, \mathrm{f}$ & $\begin{array}{c}\mathrm{a}, \mathrm{c}, \\
\mathrm{d}, \mathrm{e}, \mathrm{f},\end{array}$ & $\begin{array}{c}\text { a, c, d, } \\
\text { e,f, }\end{array}$ \\
\hline Estetik kullanım & & & & & & & & $\mathrm{a}, \mathrm{c}, \mathrm{d}, \mathrm{e}$ & & & & & & & & \\
\hline
\end{tabular}


Bitkisel tasarımın nitel özellikleri üç başlık altında toplanabilir. Bekçi (2010)'dan; (Pamay, 1979; Tanrıverdi, 1987; Carpenter ve Walker, 1990; Theodore, 1991; Uzun, 1992; Çepel, 1994; Saraçoğlu ve Uzun, 1994;Gültekin, 1994; Altınçekiç, 1996; Cengiz, 2001).

\begin{tabular}{|c|c|c|}
\hline $\begin{array}{l}\text { Bitki Materyalinin } \\
\text { Tasarım Özellikleri }\end{array}$ & $\begin{array}{c}\text { Fonksiyonel } \\
\text { yönden kullanımı }\end{array}$ & $\begin{array}{c}\text { Estetik yönden } \\
\text { kullanımı }\end{array}$ \\
\hline $\begin{array}{c}\text { a. Çizgi } \\
\text { b. Tekstür (Doku) } \\
\text { c. Form } \\
\text { d. Renk } \\
\text { e. Tekrar } \\
\text { f. Çeşitlilik } \\
\text { g. Denge } \\
\text { h. Vurgu }\end{array}$ & $\begin{array}{l}\text { a. Görsel kontrol } \\
\text { b. Hareket kontrolü } \\
\text { c. İklim kontrolü } \\
\text { d. Gürültü kontrolü } \\
\text { e. Kirlilik kontrolü } \\
\text { f. Erozyon kontrolü }\end{array}$ & $\begin{array}{l}\text { a. Tamamlayıcılar } \\
\text { b. Birleștiriciler } \\
\text { c. Vurgulayıcılar } \\
\text { d. Belirticiler } \\
\text { e. Yumuşatıcılar } \\
\text { f. Görüntüyü } \\
\text { çevreleme }\end{array}$ \\
\hline
\end{tabular}

\section{Sonuç ve Öneriler}

Corylus değerlendirildiğinde, ayırt edici dendrolojik özelliklere sahip ve bu özellikleri ile süs bitkisi olarak kullanıma uygun olduğu ortaya çıkmıştır. Büyük kısmı çalı formunda olmakla birlikte ağaççık ve ağaç formunda olanlar da mevcuttur. Bu formları ile sinırlayıcı, tamamlayıcı, destekleyici, gölge ve manzara bitkisi olarak kullanıma uygundur.

Bununla birlikte sütun, yuvarlak, dağınık, koni ve sarkık formları ile de farklı düzenlemeler için alternatiflere sahip olup, amaca uygun olarak farklı bitkisel tasarımlar teşkil edebilir. Bitkiler, pek çok farklı estetik ve fonksiyonel özelliği birlikte barındırmaktadır. Bu artıları ile Corylus türleri gölge, sınır, bitki kasası, şev bitkisi, manzara oluşturmak, perdeleme, vurgu ve fon oluşturmak gibi pek çok fonksiyon için gurup ve soliter olarak kullanılabilirler (Çizelge3,4). Ayrıca, farklı fındık tür ve formlarının fidanlıklarda üretimi de teşvik edilmelidir. Bununla birlikte, örnek oluşturması ve tanınırlığının sağlanması açısından kentlerde bir fındık koleksiyon bahçesi de oluşturulabilir. Bölgede çalışan ve bölgeye iş yapan peyzaj mimarlarının da bu bitkileri kullanması önerilebilir (Çizelge 3, 4).

$\mathrm{Bu}$ nedenlerle Corylus'un ülkemizde doğal olarak yetişen türleri yanısıra yaygın olmayan estetik ve fonksiyonel türlerinin de denenmesi ve kültürel peyzajda kullanılır hale getirilmesi önem arzetmektedir.

\section{Teşekkür}

Çalışmaya olan değerli katkı ve uzman görüşleri için Ordu Üniversitesi Ziraat Fakültesi Bahçe Bitkileri Bölümü Öğretim Üyesi Prof.Dr. Ali İSLAM'a teşekkür ederiz.

\section{Kaynaklar}

Aiello, A.,S., 2019. Farges Filbert Corylus Fargesii. (http://arnoldia.arboretum.harvard.edu/pdf/articl es/2010-68-2-farges-filbert-corylus-fargesii.pdf) , (Erişim tarihi: 01.10.2019).

Altınçekiç, H., 1996. Çilingoz koyu (Trakya) Peyzaj Planlaması Amacına Yönelik Bitki Materyalinin Saptanması, İstanbul Üniversitesi, Orman Fakültesi Dergisi, Seri A, 46.

Anonim, 2019. Cultivation of Hazelnut (Corylus sp.) in a Sugarbush. (Web sayfasi: https://www. umoncton.ca/umce-foresterie/files/umce-foresterie /wf/wf/pdf/GTHazelnut.pdf), (Erişim tarihi: 01.10.2019).

Ayan, S., Ünalan, E., Yer, E.N., Sakıcı, O. E., İslam, A. 2016. Population diversity in Northwest Anatolia Forests in terms of nut characteristics of Turkish hazelnut (Corylus colurna L.) (Kastamonu province), International Multidisciplinary Congress of Eurosia, 11-13 July, 2016, Odesa, Ukraine.

Balık, H., I., Balık, S., K., Beyhan, N., Erdoğan, V., 2016. Fındık Çeşitleri.

Bekci, B., 2010. Peyzaj Mimarlığında Değerlendirme Potansiyeli Olan Akçaağaç Yapraklı Üvez (Sorbus torminalis L. Crantz)'ın Generatif ve Vejetatif Yöntemler Kullanılarak Üretimi. Karadeniz Teknik Üniversitesi Fen Bilimleri Enstitüsü. Doktora Tezi.

Carpenter, P.L. ve Walker, T.D., 1990. Plants in the Landscape, W.H. Freeman and Company, ISBN: 07167-1808-1, Second Edition, Newyork, Oxford, 401.

Cengiz, B., 2001. Batı Karadeniz Bölgesi Doğal Bitki Örtüsünde Peyzaj Uygulamaları Amacına Yönelik Bazı Crataegus L. Taksonlarının Saptanması, Yüksek Lisans Tezi, Zonguldak Karaelmas Üniversitesi, Fen Bilimleri Enstitüsü, Bartın.

Çepel, N., 1994. Peyzaj Ekolojisi, İstanbul Üniversitesi, Orman Fakültesi, Yayın No: 3868/429, İstanbul.

Erdoğan, V., Mehlenbacher, S., A. 2002. Phlogenetic Analysis of Hazelnut Species (Corylus, Corylacae) Based on Morphology and Phenology. OT Sistematik Botanik Dergisi. 9(1):83-100.

Gültekin, E., 1994. Peyzaj Mimarlığı, Çukurova Üniversitesi, Ziraat Fakültesi, Ders Kitabı, No:58, Adana.

Günal, N., 2013. Türkiye'de İklimin Doğal Bitki Örtüsü Üzerindeki Etkileri. Çevrimiçi Tematik Türkoloji Dergisi, Yıl V, Sayı 1.

İslam A., 2018. Türkiye'de Findık Fidancılığı. TürkTob Dergisi, Sayı: 27:28-32. 
İslam, A. 2018. Hazelnut culture in Turkey. Akademik Ziraat Dergisi 7(2), 259-66.

İslam, A., Cristofori, V., Rovira, M. 2018. Hazelnut growing in Europe. MKB Yay. Ordu

Köksal, A., İ., 2002. Turkish Hazelnut Cultivars. Hazelnut Promotion Group, Ankara, ISBN: 975-92886-1-3.

Molnar, T., J., 2011. Corylus. Wild Crop Relatives: Genomic and Breeding Resources, Forest Trees, Chapter 2.

Pamay, B., 1979. Park Bahçe ve Peyzaj Mimarisi, İstanbul Üniversitesi, Orman Fakültesi, Yayın No:264, İstanbul, 371.

Peiqiong, L., Skvortsov, A., K., 1999. Betulaceae. Flora of China 4: 286-313. (Web sayfasi: http://flora.huh.harvard.edu/china/mss/volume0 4/BETULACEAE.published.pdf), (Erișim tarihi: 01.10.2019).

Saraçoğlu, Ö. ve Uzun, A., 1994. BITSEC Bitki Seçim Programı Özellikleri ve Kullanılması, İstanbul Üniversitesi Dergisi, A, 44, 2.

Schneid, C., K., 2016. Tree of the Year: Corylus fargesii. (Web sayfasi: https://www.morrisarboretum.org /pdf/IDS_16_Tree\%20of\%20the\%20Year_Corylus \%20fargesii.pdf), (Erișim tarihi: 01.10.2019).

Sensoy, S, Demircan M., Ulupınar, Y., Balta, İ., 2019. Türkiye İklimi. (Web sayfass: https://mgm.gov.tr /FILES/genel/makale/13_turkiye_iklimi.pdf), (Erișim tarihi: 02.10.2019)

Tanrıverdi, F., 1987. Peyzaj Mimarlığı Bahçe Sanatının Temel İlkeleri ve Uygulama Metodları, Ankara Üniversitesi, Ziraat Fakültesi, Yayın No: 643/291, Erzurum.

Theodore, D.W., 1991. Planting Design, Van Nostrand Reinhold.

URL,2019a. Corylus maxima Artropurpurea. (Web sayfası: http://rasadnikvasic.rs), (Erişim tarihi: 01.10.2019).

URL,2019b. Corylus avellana Purple Umbrella. (Web sayfası: https://cdn.shopify.com), (Erişim tarihi: 01.10.2019).

URL,2019c. Corylus avellana Purple Umbrella. (Web sayfası: https://www.sad-24.ru), (Erişim tarihi: 01.10.2019).

URL,2019d. Corylus heteropylla. (Web sayfası: https://landscapeplants.oregonstate.edu) , (Erişim tarihi: 01.10.2019).
URL,2019e. Corylus avellana Fusco Rubra. (Web sayfası: http://garden.virtualindustry.org/wpcontent/uploads/2008/10/corylusavellanafuscoru bra.jpg), (Erişim tarihi: 01.10.2019).

URL,2019f. Corylus avellana Fusco Rubra. (Web sayfası: https://www.blackmoor.co.uk), (Erişim tarihi: 01.10.2019).

URL,2019g. Corylus fargesii. (Web sayfası: https://www.scottarboretum.org/), (Erişim tarihi: 01.10.2019).

URL, 2019h. Corylus. (Web sayfası: https://www.vdberk.com.tr /agaclar), (Erișim tarihi: 01.10.2019).

URL,2019i. Atatürk Arboretumu Ağaç ve Çalıları. (Web sayfası: $\quad$ http://www.orman.istanbul.edu.tr/) (Erişim tarihi: 01.10.2019).

URL,2019j. (Web sayfasi: https://futureforests.ie/), (Erișim tarihi: 01.10.2019).

URL,2019k. Corylus avellana Aurea. (Web sayfası: https://www.burncoose.co.uk/), (Erişim tarihi: 01.10.2019).

URL,2019l. Corylus avellana. (Web sayfası: https://futureforests.ie/ ), (Erişim tarihi: 01.10.2019)

URL,2019m. (Web sayfası: https://worldplants.ca/), (Erişim tarihi: 01.10.2019).

URL,2019n. Corylus avellana Pendula. (Web sayfasi: http://catalogoweb.impiante.it/ ), (Erişim tarihi: 01.10.2019)

URL,2019ö. Corylus avellana Pendula. (Web sayfası: https://www.starkl-pflanzeninfothek.at/), (Erişim tarihi: 01.10.2019).

URL,2019p. Corylus avellana Fusco Rubra. (Web sayfası: https://selectree.calpoly.edu/), (Erişim tarihi: 01.10.2019)

URL,2019r. Corylus avellana Fusco Rubra. (Web sayfası: https://www.rhs.org.uk/), (Erişim tarihi: 01.10.2019)

URL,2019s. Corylus heterophylla. (Web sayfası: http://www.efloras.org/), (Erişim tarihi: 01.10.2019)

URL, 2019t. Corylus fargesii. (Web sayfası: https://pfaf.org/), (Erişim tarihi: 01.10.2019).

URL 2019u. Corylus heterophylla (Web sayfasi: https://garden.org/ ) (Erişim tarihi: 02.11.2019). 
URL, 2019y. Bitki fotoğrafları. Pinterest. (Web sayfası: https://tr.pinterest.com/) (Erişim tarihi: 02.11.2019).

Ustaoğlu, B., Karaca, M., 2014. The Effects Of Clımate Change On Spatıotemporal Changes of Hazelnut (Corylus avellana) Cultıvation Areas In The Black
Sea Region, Turkey. Applied Ecology And Environmental Research, 12(2): 309-324.

Uzun, G., 1992. Peyzaj Mimarlığında Temel Tasarım, Çukurova Üniversitesi, Ziraat Fakültesi Yardımcı Ders Kitabı, No: 9, Adana,103. 